\title{
Assessment of Wheat Optimum Density in Dryland Farming by Using Reciprocal Model
}

\author{
Salar FARHANGI-ABRIZ ${ }^{1}$, Shahram TORABIAN ${ }^{2 *}$ \\ ${ }^{1}$ University of Tabriz, Faculty of Agriculture, Department of Plant Eco-physiology, Tabriz, Iran; Farhanghi@Hotmail.com \\ ${ }^{2}$ Isfahan University of Technology, College of Agriculture, Department of Agronomy, Isfahan, \\ Iran;s.torabian@ag.iut.ac.ir (*correspondingauthor)
}

\begin{abstract}
Adjustment of seeding schemes is one of the crop management techniques that most influences grain yield. A field study was undertaken to evaluate the effects of densities on optimum wheat grain yield, biological yield and harvest index by using of reciprocal model. The treatments comprised nine wheat cultivars and five densities $\left(200,250,300,350\right.$ and 400 plants $\left.\mathrm{m}^{-2}\right)$. Evaluation analysis showed that the performance of the model was reasonable as indicated by close correspondence of simulated biomass accumulation, grain yield and harvest index with measured data. Optimum wheat density based on maximum grain yield was almost 400 plant $\mathrm{m}^{-2}$ for 'Rasad', 'Azar2', 'Homa', 'Saji', 'Koohdasht', 'Gohar' and 'Ohadi'; however,

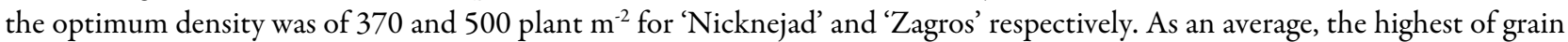
yield belonged to 'Azar2' by $414 \mathrm{~g} / \mathrm{m}^{-2}$. Biological and grain yields were dependent on the plant density, and increased when wheat density enhanced from 200 to 400 plants $/ \mathrm{m}^{-2}$.
\end{abstract}

Keywords: biological yield, grain yield, harvest index, reciprocal model, Triticum aestivum L.

\section{Introduction}

Crop productivity in semiarid regions is mainly limited by water availability (Edhaie et al., 2011). Water deficit is a major abiotic stress for crop production worldwide, limiting the productivity of crop species, especially in dry land agricultural areas (Chaves and Oliveira, 2004; Passioura, 2007). According to the prediction of current climate change models, the frequency and severity of drought will increase in several regions around the world (Shen et al., 2010). Many researchers believe that amount of crop water use determine plant growth and development. Meanwhile plants may injure under non optimal access of water at any stage (Daneshian and Jonobi, 2001; Daneshian and Zare, 2005). The response of plants to water stress depends on several factors such as developmental stage, severity, duration of stress, and planting densities.

Wheat (Triticum aestivum L.) is considered as one of the strategic crops and among the most important cereals on which the food security of countries is dependent. It grows under a broad range of latitudes and altitudes. Worldwide, wheat provides nearly $55 \%$ of the carbohydrates and $20 \%$ of the food calories consumed globally (Sing et al., 2007). Today, it is grown all over the world, with different varieties sown according to the various climates.
Seeding density is important for the wheat crop, because it directly affects the number of ears per unit area and as a consequence, other yield components such as the number of grains per ear and individual grain weight (Lioveras et al., 2004; Ozturk et al., 2006). Currently, the seeding density used for the wheat ranges from 250 to 400 viable seeds per square meter. It is, therefore, necessary to determine the optimum density of plant population per unit area for obtaining maximum yields. Plant density selection to allow for expression of maximum grain yield is a management practice that would make wheat production more economical. Stand density affects plant architecture, alters growth and developmental patterns and influences carbohydrate production. The results of previous studies showed that plant density and planting pattern differently affected biological yield and grain yield (Ferreira and Abreu, 2001). Zeidan et al. (2006) reported that grain yield and many characteristics of maize were affected by plant density.

Simulation models have been used for decades to analyze crop responses to different conditions and to test alternate management practices (Boote et al., 1996). The use of equations in density trials for determining optimal density is more efficient than analysis of variance procedures alone (Ellis et al., 1999). This is because establishing the quantitative relationships between two or more variables using mathematical equations helps to reduce the need for multi-location density trials and it is possible to extrapolate beyond actual data (Connolly, 1987). Relationship between 
540

plant density and grain yield of wheat cultivars was well described by the equations $1 / w=a+b p$ and $Y=p /(a+$ $\mathrm{bp}$ ), where $w$ is grain yield per plant, $\mathrm{p}$ is plant density and $\mathrm{Y}$ is grain yield $\mathrm{m}^{-2}$.

Thus, the hereby research was carried out to estimate optimum economic density for maximum grain yield of nine wheat cultivars in dryland farming by using reciprocal model.

\section{Materials and Methods}

Field experiments were conducted in two years (2014 and 2015) at the farm of Agricultural Research Center of East Azerbaijan, Iran (latitude $38^{\circ} 45 \mathrm{~N}$, longitude $45^{\circ} 63 \mathrm{E}$, altitude $1360 \mathrm{~m}$ above sea level). Some soil physical and chemical information is given in Table 1 . The average yearly precipitation (over a 30-year period), which occurs mostly during the autumn and winter months, is $318 \mathrm{~mm}$ for the site. The annual mean temperature is $11{ }^{\circ} \mathrm{C}$. The average temperature in 2014 was similar to the long-term meteorological data trend, while in 2015 the average temperature $\left(10^{\circ} \mathrm{C}\right)$ was lower. The plots were arranged in a randomized complete block design (RCB) with three replications of cultivars and density. These experiments were similar; the same treatments and cultivars were sown in mid-March. According to the recommended macro nutrient requirements and soil $\mathrm{N}, \mathrm{P}$ and $\mathrm{K}$ content for wheat, $130 \mathrm{~kg} \mathrm{ha}^{-1}$ urea, $80 \mathrm{~kg} \mathrm{ha}^{-1} \mathrm{P}_{2} \mathrm{O}_{5}$ (Triple Super Phosphate) and $100 \mathrm{~kg} \mathrm{ha}^{-1} \mathrm{~K}_{2} \mathrm{O}$ was supplied before seed sowing. Seeds of wheat cultivars ('Rasad', 'Azar2', 'Homa', 'Zagros', 'Saji', 'Koohdasht', 'Gohar', 'Ohadi' and 'Nicknejad') were treated with $2 \mathrm{~g} \mathrm{~kg}^{-1}$ Benomyl and then were sown in $3 \mathrm{~cm}$ depth of soil. Plant population was adjusted to 200, 250, 300, 350 and 400 plants $\mathrm{m}^{-2}$. Each plot consisted of 6 planting line with $4 \mathrm{~m}$ length, spaced $25 \mathrm{~cm}$ apart. Weeds were effectively controlled using herbicides, and no pests or disease infestations were observed during the plant growing seasons. The harvesting of experiments was accomplished manually 10 days after physiological maturity and above-ground dry biomass and grain yield were measured. The dry weights of all plant samples were determined after oven drying at $80{ }^{\circ} \mathrm{C}$ for $48 \mathrm{~h}$. Subsequently, biological yield and grain yield per unit area were recorded.

The most common model that relate individual plant yield to population density is a reciprocal equation proposed by Holliday (1960):

$$
1 / \mathrm{w}=\mathrm{a}+\mathrm{bp} \text { (Equation } 1) \text {, }
$$

where ' $\mathrm{w}$ ' is individual plant weight or yield, ' $\mathrm{p}$ ' is plant density, and ' $a$ ' and 'b' are constants. This linear form of the equation describes an asymptotic response of area yield to plant density, whereas expansion to a quadratic equation describes a parabolic response. Biological meaning is ascribed to the parameters: $1 / \mathrm{a}$ is the plant yield at low density representing genetic potential and $1 / \mathrm{b}$ is the area yield at high density representing environmental potential. These attributes of the reciprocal form were cited as reasons for preference by Wiley and Heath. The values of $a$ and $b$ (estimated by equation 1) can be used in equation 2 to determine crop yield per unit area $(\mathrm{Y})$ at different plant population densities:

$$
\mathrm{Y}=\mathrm{p} /(\mathrm{a}+\mathrm{bp})(\text { Equation } 2)
$$

Optimum densities for each cultivar determined with equation 1 and 2. Excel software was used to draw figures.

Several statistics methods were used to compare the simulated and observed results. In this paper evaluated model performance using the root mean square error normalized (RMSEn) (Rinaldy et al., 2003):

$$
\operatorname{RMSE}_{\mathrm{n}}=100\left(\sum_{i=1}^{n}\left(P_{i}-O_{i}\right)^{2} / n\right)^{0.5} / O_{\text {mean }}
$$

Where $\mathrm{Pi}$ is the simulated value, $\mathrm{Oi}$ is the measured value and $n$ is the number of measurements. RMSE was stated as percentage of simulated amounts than observed amounts. So according to above descriptions, RMSE $<10 \%$ is excellent, $10 \%<\mathrm{RMSE}<20 \%$ is well, $20 \%<\mathrm{RMSE}<30 \%$ is moderate, RMSE $>30 \%$ is weak (Rinaldy et al., 2003).

\section{Results and Discussion}

The mean reciprocal data for biological and grain yields per plant are described by equation $1[1 / \mathrm{w}=\mathrm{a}+\mathrm{bp}]$ (Figs. 1 and 2). Thus, regression coefficients obtained from equation 1 were used in equation $2[\mathrm{Y}=\mathrm{p} /(\mathrm{a}+\mathrm{bp})]$ and the relations of plant density with biological and grain yields were determined (Figs. 3 and 4). Martin and Field (1987) indicated that yield density relationships for grain may sometimes be better described by asymptotic models. In the all wheat cultivars, higher plant population gave much lower weights of individual plant. In other words, biological and grain yields of one plant declined with increasing seeding density (Figs. 1 and 2). These findings confirm the report of Thom (1977). The highest of regression coefficient (0.93) between plant density with biological and grain yields belonged to Zagros and Gohar; however, the lowest was recorded in Nicknejad.

The highest plant biomass, grain yield and harvest index at different densities were produced by 'Homa' $\left(914 \mathrm{~g} \mathrm{~m}^{-2}\right)$, 'Azar2' (414 $\left.\mathrm{g} \mathrm{m}^{-2}\right)$ and 'Ohadi' (50.8\%), respectively (Table 2). Varga et al. (2001) indicated that there was significant correlation between grain yields of different wheat genotypes. According to Table 2, the model can successfully predict biological and grain yields changes of wheat at

\begin{tabular}{|c|c|c|c|c|c|c|c|c|c|c|c|c|}
\hline Property & Sand & Silt & Clay & $\begin{array}{c}\text { Water } \\
\text { retention } \\
0.33 \mathrm{bar}\end{array}$ & $\begin{array}{c}\text { Water } \\
\text { retention } \\
15 \text { bar }\end{array}$ & $\mathrm{pH}$ & EC & $\begin{array}{l}\text { Organic } \\
\text { carbon }\end{array}$ & $\begin{array}{c}\mathrm{KMNO}_{4} \\
\mathrm{~N}\end{array}$ & $\begin{array}{l}\text { Olsen- } \\
\text { P }\end{array}$ & $\begin{array}{c}\mathrm{NH}_{4} \mathrm{OAc}- \\
\mathrm{K}\end{array}$ & $\begin{array}{c}\text { Available soil } \\
\text { moisture }\end{array}$ \\
\hline Unit & $\%$ & $\%$ & $\%$ & $\mathrm{~g} 100 \mathrm{~g}^{-1}$ & $\mathrm{~g} 100 \mathrm{~g}^{-1}$ & & $\operatorname{mmos} \mathrm{cm}^{-1}$ & $\%$ & $\mathrm{~kg} \mathrm{ha}^{-1}$ & $\mathrm{~kg} \mathrm{ha}^{-1}$ & & $\begin{array}{c}\mathrm{mm} 180 \mathrm{~cm}^{-1} \\
\text { soil }\end{array}$ \\
\hline 2014 & 60 & 30 & 10 & 11.3 & 4.2 & 7.4 & 0.11 & 0.38 & 105 & 14.7 & 195 & 219 \\
\hline 2015 & 60 & 30 & 10 & 11.9 & 3.8 & 7.3 & 0.11 & 0.36 & 118 & 11.9 & 231 & 248 \\
\hline
\end{tabular}
different plant densities.

Table 1. Some physical and chemical characteristics of the experimental soil 
Dry matter accumulation and grain yield influenced strongly wheat densities. As shown in Fig. 3, biological yield of all wheat cultivars rapidly increased with increasing plant population density up to 400 plants $\mathrm{m}^{-2}$ and thereafter slowed down. Similar trend was shown for grain yield per unit area up to 400 plants $\mathrm{m}^{-2}$ (Fig. 4). Regression coefficient had high and positive correlation $\left(\mathrm{R}^{2}>0.95\right)$ between biological and grain yields with plant density (Figs. 3 and 4).

Optimum economic density of grain yield was estimated almost 400 plants $\mathrm{m}^{-2}$ for 'Rasad', 'Azar2', 'Homa', 'Saji', 'Koohdasht', 'Gohar' and 'Ohadi'; however, were 370 and 500 plant $\mathrm{m}^{-2}$ for 'Nicknejad' and 'Zagros', respectively (Table 2). The original objective of agricultural producers to maximize yield has been changed to protect environmental quality. Farmers must consider environmental issues; therefore, they have more constraints on their management decisions. Crop simulation models have become a useful tool to characterize and quantify yield under different conditions, such as plant density, sowing date and environmental stress. The reciprocal model was evaluated for simulations of biomass, and grain yield of wheat cultivars. There was a close match between simulated and measured.

Plant density is one of the main factors determining the ability of the crop to capture resources; it is of particular importance because it is under fairly close control by farmer in most wheat producing systems. It may be strongly difficult to disentangle the effects of crop density from those of other factors, under extensive grain production (Snaydon, 1984). However, there has been interest in defining the relationships between density and crop yield quantitatively in order to establish optimum populations and maximum attainable yields under various situations. As a result, the effect of density on wheat plant size and crop productivity has received attention (Harper, 1977). The management of crop competition through density selection may allow maximum yields per unit area to be achieved. In general, planting densities chosen for field wheat crops are aimed to produce a crop able to use all above and belowground resources, allowing the crop to maximize growth rates during growth.

The target plant density is essentially that value of plant population density at which the grower believes economic returns will be maximized. Yield density relations can be parabolic (i.e. yield increase up to a certain density but further increase in density reduces yield), or asymptotic (i.e. yield increases towards a plateau value) (Holliday, 1960). Relations between yield and plant population in the temperature cereals and in oilseed rape are asymptotic (Ellis et al., 1999). If asymptotic yield density relations are quantified in this way, then it is possible to determine optimum plant population densities for different scenarios.

Table 2. Optimum densities and maximum biological and grain yields at different wheat cultivars by reciprocal model

\begin{tabular}{|c|c|c|c|c|c|c|}
\hline Cultivar & $\begin{array}{l}\text { Optimum densities for } \\
\text { biological yield } \\
\text { plant } \mathrm{m}^{-2}\end{array}$ & $\begin{array}{c}\text { Maximum } \\
\text { biological yield } \\
\mathrm{g} \mathrm{m}^{-2}\end{array}$ & $\begin{array}{l}\text { Optimum densities for } \\
\text { grain yield } \\
\text { plant } \mathrm{m}^{-2}\end{array}$ & $\begin{array}{l}\text { Maximum grain } \\
\text { yield } \\
\mathrm{g} \mathrm{m}^{-2}\end{array}$ & $\begin{array}{c}\text { Biological yield at } \\
\text { maximum grain yield } \\
\qquad \mathrm{g} \mathrm{m}^{-2}\end{array}$ & $\begin{array}{l}\text { Harvesting index at } \\
\text { maximum grain yield }\end{array}$ \\
\hline 'Rasad' & 393 & 866.21 & 389 & 385.40 & 866.08 & 44.49 \\
\hline 'Azar2' & 394 & 875.89 & 387 & 414.71 & 875.40 & 47.37 \\
\hline 'Homa' & 418 & 914.34 & 408 & 382.27 & 914.42 & 41.80 \\
\hline 'Zagros' & 475 & 822.83 & 502 & 375.86 & 819.77 & 45.84 \\
\hline 'Saji' & 442 & 806.73 & 410 & 345.14 & 804.28 & 42.91 \\
\hline 'Koohdasht' & 407 & 739.44 & 466 & 337.10 & 716.81 & 47.02 \\
\hline 'Gohar' & 400 & 761.74 & 396 & 354.29 & 763.35 & 46.41 \\
\hline 'Ohadi' & 446 & 744.86 & 401 & 375.67 & 739.08 & 50.82 \\
\hline 'Nicknejad' & 368 & 819.45 & 370 & 373.14 & 819.42 & 45.53 \\
\hline RMSEn (\%) & 10.3 & 8.42 & 12.81 & 15.7 & 10.6 & 9.27 \\
\hline
\end{tabular}
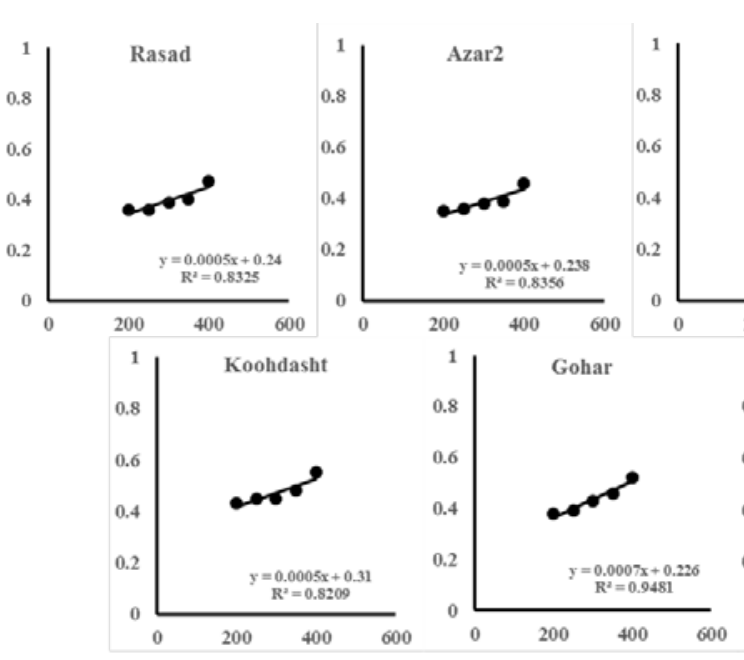

(1)

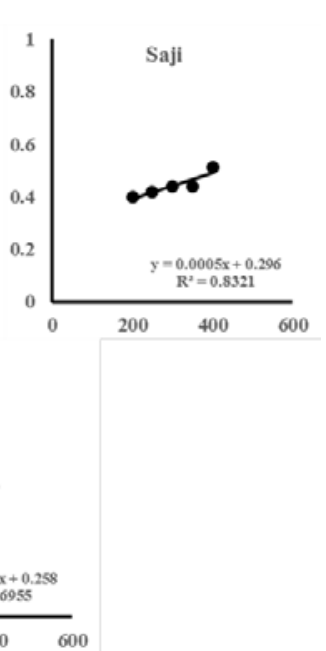

Fig. 1. Relations between the reciprocal of biological yield per plant and plant density. $\mathrm{X}$ axis: Plant population (plant $\mathrm{m}^{-2}$ ); $\mathrm{Y}$ axis: $1 / \mathrm{w}(1 / \mathrm{g})$ 

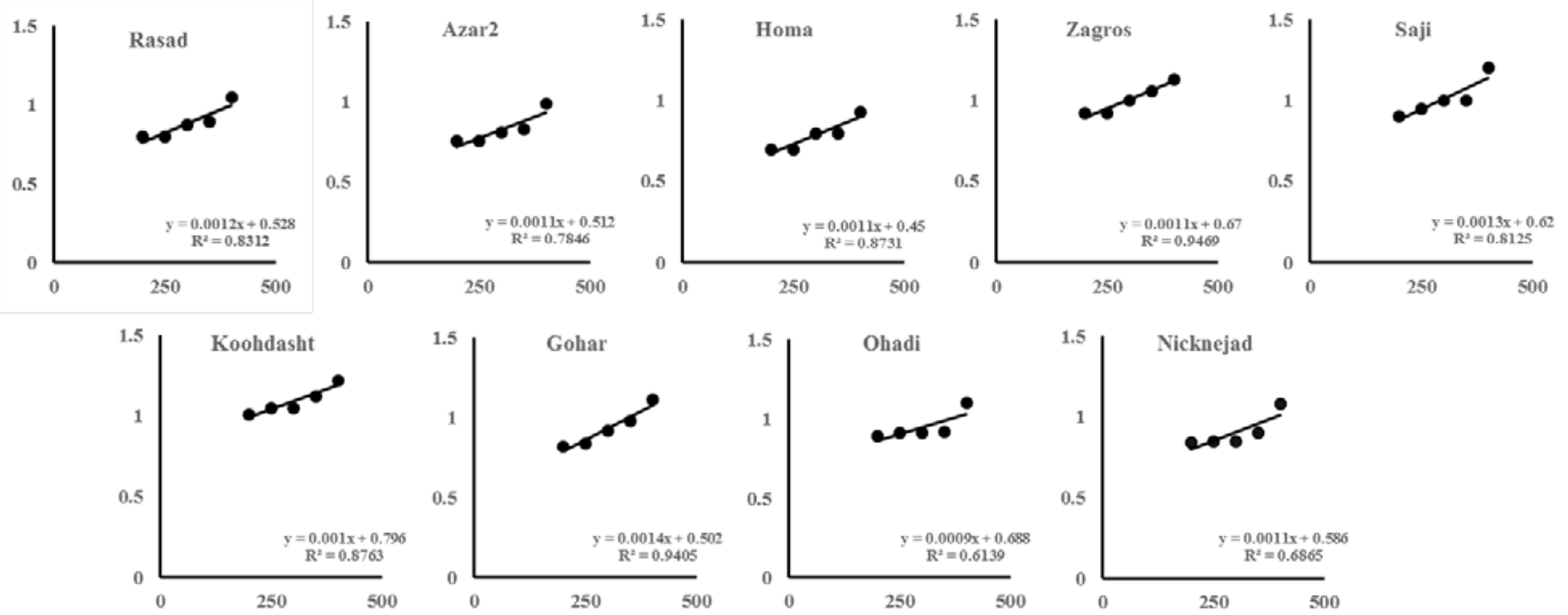

Fig. 2. Relations between the reciprocal of grain yield per plant and plant density. $\mathrm{X}$ axis: Plant population $\left(\right.$ plant $\left.\mathrm{m}^{-2}\right)$; $\mathrm{Y}$ axis: $1 / \mathrm{w}(1 / \mathrm{g})$
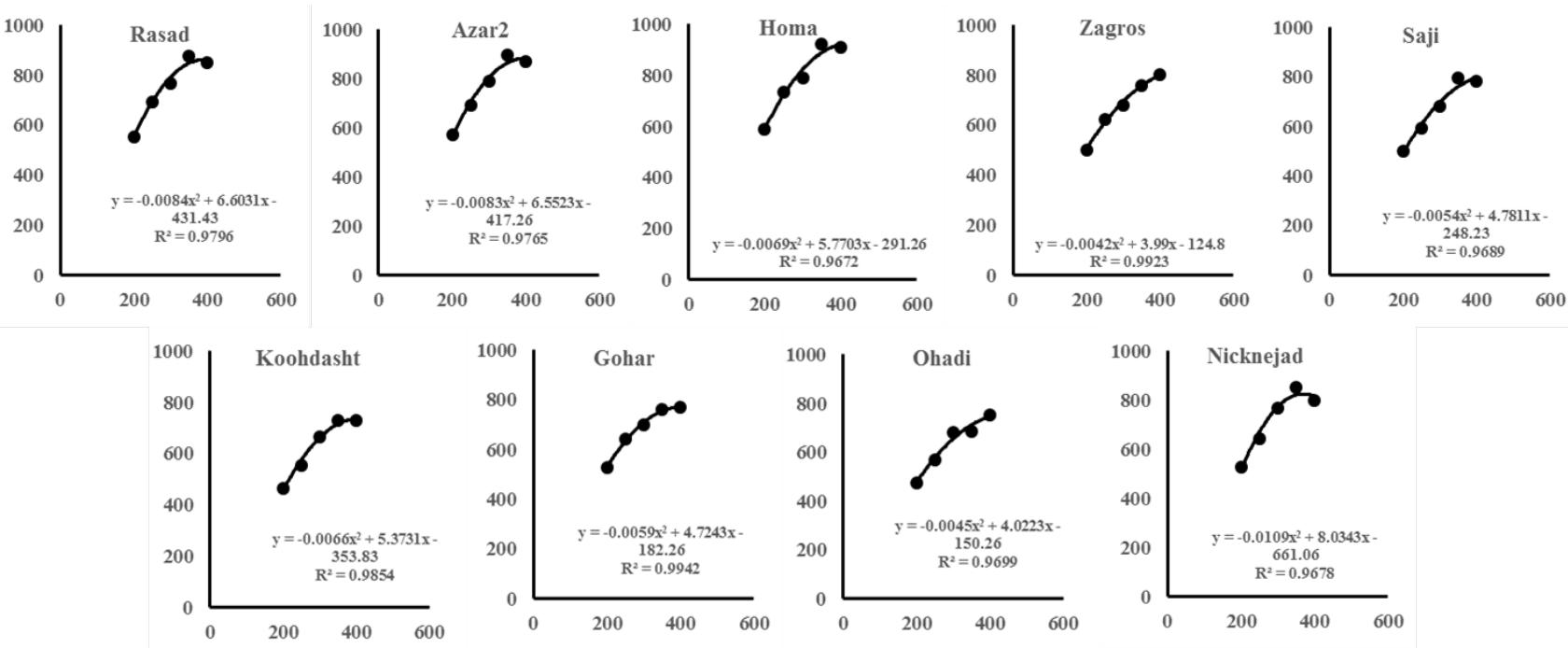

Fig. 3. Relations between the biological yield per unit area and plant density in wheat cultivars. X axis: Plant population (plant $\left.\mathrm{m}^{-2}\right)$; Y axis: Biological yield $\left(\mathrm{g} \mathrm{m}^{-2}\right)$
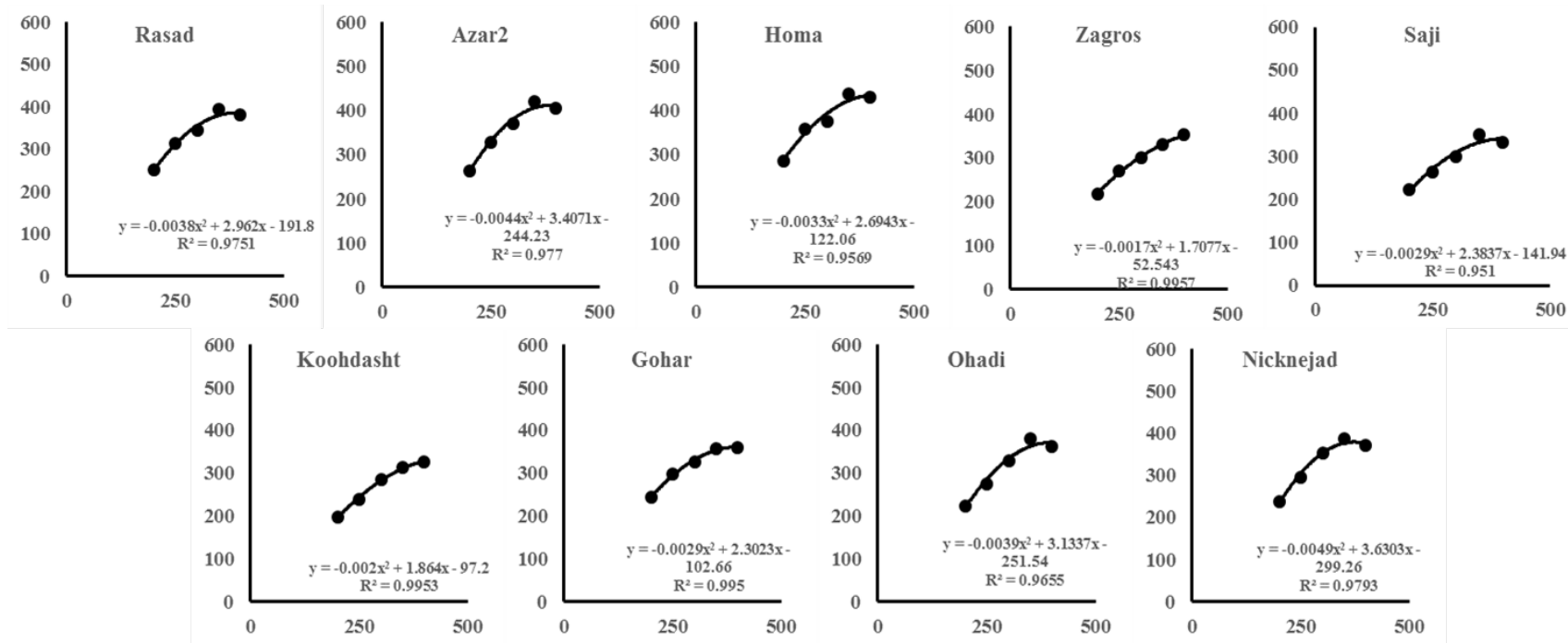

Fig. 4. Relations between the grain yield per unit area and plant density in wheat cultivars. $\mathrm{X}$ axis: Plant population $\left(\mathrm{plant} \mathrm{m}^{-2}\right) ; \mathrm{Y}$ axis: Grain yield $\left(\mathrm{g} \mathrm{m}^{-2}\right)$ 
Simplistically, the economic optimum is that point on the asymptotic relation where the increase in the value of the crop equals the cost of extra seed. Wheat plants have the ability to compensate for low plant populations by producing more tillers. The total shoot weight of wheat per unit area of land usually increases asymptotically as density increases (Holliday 1960).

\section{Conclusions}

The research was carried out for simulating wheat dry matter and grain yield by using reciprocal model in dryland farming. Results showed that the applied model can simulate grain and biomass yields of wheat. The seeding density for wheat should take into account cultivar tillering potential and location. Cultivars with low tillering potential express higher effect on grain yield, as a function of an increase in seeding density. Optimum density for maximum grain yield in majority of wheat cultivars was almost 400 plant $\mathrm{m}^{-2}$.

\section{References}

Boote KJ, Jones JW, Pickering NB (1996). Potential uses and limitations of crop models. Agronomy Journal 88:704716.

Chaves MM, Oliveira MM (2004). Mechanisms underlying plant resilience to water deficits: prospects for water-saving agriculture. Journal of Experimental Botany 55:2365-2384.

Connolly J (1987). On the use of response models in mixture experiments. Oecologia 72:95-103.

Daneshian J, Jonobi P (2001). Effect of drought stress and different calcium on characters' soybean. Agricultural Science 1:95-108.

Daneshian J, Zare D (2005). Diversity for resistance drought on soybean. Journal of Agricultural Science 1:23-50.

Ehdaie B, Andrew PL, Waines JG (2011). Root system plasticity to drought influences grain yield in bread wheat. Euphytica 31:1282-1288.

Ellis R H, Salahi M, Jones SA (1999). Yield-density equations can be extended to quantify the effect of applied nitrogen and cultivar on wheat grain yield. Annals of Applied Biology 134:347-352.

Ferrrira AM, Aberu FG (2001). Description of development, light interception and growth of sunflower at two sowing dates and two densities. Portugal, Elsevier Science pp 369-383.
Harper JL (1977). Population biology of plants. Academic Press London.

Holliday R (1960). Plant population and crop yield: part I: Field Crop Abstracts 13:159-167.

Lloveras J, Manent J, Viudas J, López A, Santiveri P (2004). Seeding rate influence on yield and yield components of irrigated winter wheat in a Mediterranean climate. Agronomy Journal 96:1258-1265.

Martin MP, Field RJ (1987). Competition between vegetative plants of wild oat (A. fatua) and wheat (Triticum aestivum L.). Weed research 27:119124.

Ozturk A, Caglar O, Bulut S (2006). Growth and yield response of facultative wheat to winter sowing freezing sowing and spring sowing at different seeding rates. Journal of Agronomy and Crop Science 192:1016.

Passioura J (2007). The drought environment: physical, biological and agricultural perspectives. Journal of Experimental Botany 58:113-117.

Rinaldy-Losavio MN, Flagella Z (2003). Evaluation of OILCROP-SUN model for sunflower in southern Italy. Agricultural Systems 78:17-30.

Shen X, Zhou Y, Duan L, Li Z, Eneji AE, Li J (2010). Silicon effects on photosynthesis and antioxidant parameters of soybean seedlings under drought and ultraviolet- $\mathrm{B}$ radiation. Journal of Plant Physiology 167:1248-1252

Singh H, Singh AK, Kushwaha L (2007). Energy consumption pattern of wheat production in India. Energy 32:1848-1854.

Snaydon RW (1984). Infraspecific variation and its taxonomic implications. In: Heywood VH, Moore DM (Eds). Current concepts in plant taxonomy. Academic Press, London and Orlando pp 203-218.

Thom ER (1977). The effect of plant population and time of harvest on growth of hybrid and non-hybrid maize. Proceeding of the Agronomy Society of NewZealand7:75-80.

Varga B, Svecngak I, Pospisil I (2001). Winter wheat cultivars performance as affected by production systems in Carotia. Agronomy Journal 93:961966.

Zeidan MS, Amany A, El-Kramany MF (2006). Effects of N-fertilizer and plant density on yield and quality of maize in sandy soil. Research Journal of Agriculture and Biological Sciences 2:156-161. 